\title{
TEORI-TEORI GEOGRAFI: PEMIKIRAN KEARAH PENGEMBANGAN
}

Oleb: Tadjuddin Noer Effendi

\section{Pendahuluan}

Sampai saat ini masyarakat geografi masih terlibat dalam pembicaraan dan perbedaan mengenai metodologi geografi. Patut diakui usaha itu telah melahirkan pemikiran-pemikiran baru dalam metodologi. Namun, tanpa disadari perdebatan yang cukup melelahkan itu telah melemahkan, bahkan ada kecenderungan meragukan kedudukan geografi sebagai cabang ilmu. Akibatnya, pengembangan teori-teori yang amat dibutuhkan dalam ilmu pengetahuan mengalami kelambatan.

Sebenarnya hal itu tak perlu terjadi karena metodologi geografi ditinjau dari sudut pandang ulmu pengetahuan (scientific methodology) sudah memenuhi kaidah-kaidah ilmu pengetahuan (Harvey, 1973; Smith, 1979; Stoddart, 1981; Browett, 1983). Namun, geografi sebagai cabang ilmu pengetahuan tergolong lambat dalam mengem. bangkan teori. Harvey (1973: 135) mengatakan bahwa kelambatan ini selain bersumber dari kekhawatiran dan keraguan terhadap metodologi ilmiah, ju. ga disebabkan oleh lemahnya pengertian tentang pentingnya teori dalam penjelasan ilmiah yang pada gilirannya gagal menyusun pernyataan-pernyataan verbal yang menuruti logika ilmiah. Hal ini mengisyaratkan bahwa geografi kurang atau belum mampu menjelaskan gejala-gejala dan fakta-fakta empiris ke dalam hal, penelitian-penclitian geografi terperangkap ke dalam penjelasan-penjelasan detail yang sulit dimengerti dan dipahami oleh masyarakat ilmiah.

Menyadari kekurangan itu maka sudah tiba saatnya bagi para pakar geografi mulai mengalihkan perhatian dan pemikiran untuk mengembangkan teori-teori geografi. Risalah ini berusaha membahas pokok-pokok pikiran ke arah pengembangan teori-teori geografi. Bahasan di bagi dalam dua bagian. Pertama, membahas apa arti teori dan mengapa ia dibutuhkan dalam ilmu pengetahuan. Kedua, bagaimana cara mengembangkan teori geografi dengan menampilkan beberapa contoh.

\section{Teori dan Kegunaannya}

Teori adalah suatu ide yang bersifat abstrak atau umum yang disimpulkan dari hasil pengamatan atau fakta-fakta cmpiris (Babbie, 1989: 30-31), dan merupakan unsur penting dalam ilmu pe. ngetahuan. Tanpa teori, pengamatan dan fakta-fakta empiris tak dapat diterangkan secara logis dan runtut. Pengamatan atau fakta-fakta untuk dapat diangkat menjadi teori harus mengandung logika (penalaran) ilmiah. Artinya, tidak semua kesimpulan yang ditarik dari pengamatan dan fakta-fakta empiris dapat dikatakan teori. Sebab tidak tertutup kemungkinan kesimpulan itu ditarik secara intuitif; scorang langsung menarik suatu kesimpulan tanpa melalui tahapan-tahapan berfikir sccara analistis. Kesimpulan intuitif 
tidak selamanya salah, tetapi ia mengandung kelemahan karena tidak dapat menjelaskan mengapa sampai pada kesimpulan tersebut.

Salah satu kegiatan ilmiah adalah membangun teori atau menjelaskan (explanation). Karenanya, berpikir analistis lebih dominan daripada berpikir intuitif. Kesimpulan yang ditarik secara intuitif merupakan salah satu sebab penghambat dalam pengembangan teori. Jadi, teori harus didasrkan pada analisis epistemologi2 keilmuan, dan bukan disimpulkan (penalaran). Pengembangan teori berarti menggabungkan pikiran rasional yang sistematis dengan pikiran empiris dalam rangka mencari kebenaran.

Dalam membangun teori diperlukan kriteria kebenaran. Menurut Suriasumantri (1990: 7) kriteria kebenaran ada tiga macam. Pertama, koherensi yang didasrkan pada konsistensi alur pemikiran (argumentasi), Bila konsistensi berpikir runtut maka kesimpulan atau teori dapat dikatakan memenuhi kaedah-kaedah ilmiah. Jadi teori tidak akan memenuhi syarat ilmiah bila konsistensi dalam argumentasi tidak runtut. Alur pemikiran dalam berargumentasi juga harus bersifat koheren; artinya terpadu secara utuh. Koherensi ini amat penting untuk pengembangan teori yang bersifat sistematis dan konsisten. Kedua, korespondensi yang didaasrkan pada kesesuaian materi dengan obyek bahasan (fakta-fakta empiris). Bila diuji teori tersebut akan benar. Dapat dikatakan bahwa korespondensi mengandung arti kebenaran sesuai dengan kenyataan yang dapat diuji kebenarannya. Ketiga, pragmatisme didasarkan pada berlaku atau tidaknya suatu teori dalam lingkup ruang dan waktu. Ini mengandung pengertian bahwa suatu teori secara fungsional mampu menjelaskan, meramalkan, dan mengontrol suatu gejala alam dalam kurun waktu tertentu. Bila syarat itu terpenuhi maka secara pragmatis teori itu benar ${ }^{3}$. Bila dalam kurun waktu tertentu teori ini tidak dapat berfungsi lagi maka kebenaran dapat dialihkan pada teori lain yang lebih berfungsi. Jadi secara pragmatis ilmu pengetahuan memberikan pilihan-pilihan terhadap teori yang lebih meyakinkan dan bersifat umum (universal). Dengan demikian dapatlah disimpulkan bahwa teori tidak hanya rasional, konsisten, dan sistematis, tetapi juga harus teruji kebenarannya. Sifat-sifat ini menjadikan teori sebagai unsur penting dalam ilmu pengetahuan.

Apa guna teori? Menurut Harvey (1973: 89) teori mempunyai dua fungsi dalam kegiatan ilmiah. Pertama, teori dapat menterjemahkan pengamatan dan fakta-fakta empiris dan membatasi ranah pembahasan. Lebih penting lagi teori adalah berfungsi sebagai landasan berpikir dalam pengembangan teori.

\section{PENGEMBANGAN TEORI GEOGRAFI}

Dalam membangun teori geografi, sifat studi geografi (nature of geography) merupakan dasar pemikiran dan prinsip-prinsip yang harus dianul (Johnston, 1980). Kerangka pemikiran ini telah ditanamkan dalam tradisi (perspektif) geografi dan telah banyak dibahas dalam literatur-literatur geografi (lihat misalnya, Hartshorne, 1959: Bintaro dan Surastopo, 1979: 12-26). Masalah yang acap kali ditemui adalah bagaimana mengidentifikasi dan menerapkan secara tepat ide dan konsepkonsep yang ada dalam literatur ke dalam kerangka pemikiran penelitianpenelitian geografi. Kesulitan ini sering 
membuat seorang geografiwan kehilangan arah studinya dan kesimpulan. kesimpulan yang dihasilkan menjadi dangkal dan kabur. Menurut Harvey (1973: 114) hal itu dapat diatasi dengan mengacu pada paradigma studi geografi. Meskipun ada beberapa pendapat tentang paradigma studi geografi, Haggett (1966: 10-13) menyarankan bahwa para geografiawan cenderung mengelempokkan pemikiran mereka kedalam lima paradigma, yakni differensiasi areal (areal differentiation), bentang alam (lansdcape), manusia dan lingkungannya (man-environment), distribusi keruangan (spatial distribution) dan geometrik (geometric). Kelima paradigma ini harus dijadikan dasar dalam menbuat definisi operasional dan memformulasikan konsep dan teori. Dengan demikian para geografiawan dapat dengan mudah dan jelas mengumpulkan faktafakta empiris dan membangun teori seperti cabang ilmu yang lain.

Paradigma geografi juga dapat ber. tindak sebagai sebuah acuan yang dapat menunjukkan fakta-fakta empiris yang harus dikumpulkan dan menyarankan organisasi (metodology) yang dipakai dalam mengumpulkan faktafakta empiris itu (Harvey clan Holly, 1981). Di samping itu sifat studi geografi juga menyediakan secara kasar definisi ranah penelitian-penclitian geografi dan karenanya ia dapat dipakai dalam menentukan ranah studi geografi. Setiap paradigma studi geografi juga bertindak sebagai seperangkat instruksi bagaimana seorang geografiawan harus melakukan penelitian karena dia akan membatasi pertanyaan-pertanyaan bagaimana faktafakta terintegrasi dalam konteks paradigma geografi, misalnya dalam konteks ruang (areal context) atau kekurangan?. Dalam menjawab postu. lat yang menjadi dasar teori dan menguji secara teliti. Setiap konsep mungkin secara otomatis dapat dijadikan postulat dasar untuk membangun teori.

Konsep dan postulat dalam geografi dapat dikembangkan dengan dua cara (Harvey, 1973: 130). Pertama, berdasarkan konsep derivatif. Konsep derivatif ini ada dua tipe. Tipe pertama adalah konsep yang bersumber dari geografi, kemudian dipakai oleh cabang ilmu lain. Tipe kedua adalah konsep yang dibangun bersumber dari konsep cabang ilmu pengetahuan lain yang kemudian dipinjam untuk menje. laskan fenomena geografi. Konsep tipe kedua ini kadangkala dapat menimbulkan salah pengertian di kalangan geografiawan. Mereka sering menanyakan apakah studi geografi yang menggunakan konsep cabang ilmu pengetahuan lain, studinya dapat dikatakan studi geografi? Tidak jarang masalah ini dijadikan perdebatan di kalangan geografiawan. Menurut Harvey (1973: 117. 118) pinjam meminjam konsep dalam ilmu pengetahuan amat lazim dilakukan dan tidak akan berpengaruh pada keabsahannya sebagai karya ilmiah asal menuruti penalaran dan logika ilmiah. Geografiawan dapat melakukan hal yang sama, namun dalam mencrapkan konsep pinjaman itu geografiawan harus membuat sintesa dengan cara mengkaitkan konsep-konsep derivatif tersebut dengan pendekatan-pendekatan geografi seperti bentuk dan struktur keruangan. Contoh konsep tipe kedua itu menurut Harvey (1973: 118) ialah teori lokasi. Teori lokasi pada dasrnya adalah ekonomi, kemudian dipinjam oleh geografi dan melahirkan teori central place. Contoh lain adalah kon. sep involusi perkotaan (urban involution) yang dikembangkan olch seorang 
geografiawan bernama McGee (1971), untuk menjelaskan proses urbanisasi dan perkembangan perekonomian kota negara-negara sedang berkembang. Konsep itu dipinjam dari konsep involusi pertanian (agricultural involution) yang dikembangkan oleh Geertz (1963), seorang antropologi. Dalam mengembangkan konsep involusi pertanian menjadi konsep involusi perkotaan, McGee memasukkan variabel ke ruangan dalam sintesanya, khusus interaksi desa kota. Konsep transisi mobilitas yang dikembangkan oleh Zelinsky dapat dikategorikan sebagai konsep derivatif. Dalam mengembangkan konsep itu Zelinsky (1971; 229-249) berusaha menerapkan konscp pertum. buhan bertahap (stage of growth) dari Rostow (1958: 154-188). Zelinsky menerapkan teori itu dan mensistesakannya dengan konsep transisi mobilitas. Contoh-contoh ini menyarankan bahwa dalam mengembangkan teori geografi, geografiawan dapat meminjam konsep yang dikembangkan olch cabang ilmu pengetahuan lain.

Kedua adalah konsep yang dikembangkan dari disiplin geografi sendiri. Menurut Harvey (1973: 124) banyak konsep yang telah dikembangkan dengan cara-cara yang kurang memenuhi kaedah-kaedah ilmu pengetahuan. Sayangnya, Harvey tidak memberikan contoh konsep geografi yang tidak memenuhi syarat ilmiah itu. Dasar pembentukan teori formal geografi dapat dilakukan dengan cara (Harvey, 1973: 130):

1. Menguraikan postulat dengan jeias dan mengembangkannya dengan perhitungan yang tepat (appropriate calculus).

2. Penggunaan teknik model-model yang sesuai dengan masalah- masalah geografi. Cara pertama telah ba- nyak disinggung pada bagian terdahulu. Aagar mudah dimengerti diajukan contoh yang dikembangkan oleh Harvey (1973: 130). Katakanlah kita akan menerapkan paradigma manusia dan lingkungan sebagai dasar pembentukan teori. Teori yang kita kembangkan adalah teori kendali lingkungan (environtmental contro) untuk menjelaskan keterbatasan-keterbatasan sistem pertanian di suatu dacrah. Untuk ini dapat diajukan dua postulat yakni,

1. Bila suatu sistem pertanian dalam suatu lingkungan alam tertentu memiliki keuntungan-kcuntungan alami sedang sistem pertanian yang la. in kekuranganakan hal ini maka sistem pertanian itu akan atau sangat mungkin bertahan dan berkembang.

2. Bila suatu sistem pertanian dalam suatu lingkungan alam tertentu ku. rang atau tidak mempunyai keuntungan alami, sedang sistem bertahan dan berkembang.

Konsep di atas masih sangat abstrak, maka agar dapat diukur konsepkonsep itu perlu diterjemahkan ke dalam definisi operasional Pertama kita perlu membuat definisi tentang apa yang dimaksud dengan lingkungan yang menguntungkan. Lingkungan yang menguntungkan tidak dapat hanya didefinisikan dengan melihat karakteristik saja. Definisi itu perlu dikaitkan dengan distribusi aktual sistem pola tanam (cropping system). Ini mengharuskan kita menelusuri,

kondisi fisik yang dibutuhkan untuk pengembangan tiap sistem pertanian,

menunjukkan bahwa tiap lingkungan memiliki tiap karekteristik itu, dan

menunjukkan bahwa ada suatu sistem pertanian yang kondisi- kondisi fisiknya dapat memberikan hasil yang 
erbak dalam suatu lingkungan terten$=$

Dengan cara itu kita akan dapat mombuktikan bahwa teori kendali lingingan dapat dijadikan dasar meru. =uskan postulat yang berkaitan dengan kondisi-kondisi fisik yang dibutzian untuk pengembangan suatu sis$1 c=$ pertanian. Tanpa bantuan postulat ma. verifikasi fakta-fakta empiris suatu mori tidak akan dapat dicapai. Jadi, nembangun teori harus berawal dari actori. Pembahasan bagaimana menurunkan teori menjadi postulat dan mengembalikannya pada teori lagi tidak Iidiskusikan secara detail dalam risa. bh ini. Contoh ini secara detail dipaparkan oleh Harvey dalam buku Explamation in Geography (1973:130-135)

Cara kedua adalah dengan membangun model. Chorley dan Hagget (1967) teah banyak mengembangkan model yang dapat dikembangkan dalam studi geografi. Bintarto dan Suras. topo (1979) telah menerapkan beberapa model geografi ke dalam kondisi Indonesia. Hugget (1980) mengembangkan berbagai model yang dipakai dalam studi geografi, khususnya dari perspektif analisis sistem. Menurut Harvey (1973:141) fungsi model adalah sebagai alat yang memungkinkan untuk menyederhanakan interaksi yang komplek ke dalam bentuk yang lebih nyata (visual). Secara normatif model me. mungkinkan untuk melakukan perbandingan. Secara metodologi ia dapat berfungsi sebagai alat untuk mengumpulkan dan analisis data dan penjelasan langsung. Lebih penting lagi model adalah alat konstruksional dalam mencari teori-teori geografi atau mengembangkan teori-teori yang sudah ada. Melihat fungsi model, maka para geografiwan, terutama mercka dari geografi fisik dapat menggunakan mo- del dalam pengembangan teori. Hug. get (1980) menawarkan model untuk pengembangan teori dalam geografi fisik. Tetapi tidak tertutup kemungkinan bahwa geografi manusia juga meng. gunakan model dalam pengembangan teorinya. Salah satu contoh penggunaan model dalam pengembangan teori adalah model yang dipakai oleh Rondinelli (1985:51-52). Rondinelli membangun teorinya berdasarkan pada paradigma manusia dan lingkungan. Teori yang akan dikembangkan adalah integrasi fungsional yang digunakan untuk menjelaskan distribusi keruang. an pola pemukiman (settlement) dalam kaitannya dengan pengembangan wilayah. Bersumber pada teori itu diajukan postulat,

\begin{abstract}
berbagai macam ukuran (sizes) pemukiman dan ciri-ciri fungsional, kbususnya pusat pelayanan dan pasar mempunyai peranan yang penting dalam pengembangan wilayab. Namun, di negaranegara sedang berkembang sistem pemukiman (seltlement) belum terjalin dan terintegrasi sebingga pusat kegiatan tidak berfungsi secara efektif dalam pengembangan wilayah.
\end{abstract}

Dengan menggunakan pendekatan fungsi wilayah dalam pengembangan pedesaan Rondinelli membangun model analisisnya seperti ditampilkan dalam Lampiran 1. Atas dasar model itu diturunkan beberapa variabel yang diperlukan dalam analisis seperti,

1. Penduduk dan karakteristik sosial

2. Karakteristik wilayah.

3. Karakteristik ekonomi.

4. Karakteristik penduduk dalam hubungannya dengan karakteristik wilayah. 
5. Karakteristik penduduk dalam hubungannya dengan aktivitas ekonomi.

6. Karakteristik wilayah dalam hubungannya dengan aktivitas ckonomi.

Variabel ini, kemudian, menjadi dasar untuk pengumpulan data dan faktafakta empiris. Setclah diuji dengan berbagai metode Rondinelli sampai pada kesimpulan (teori) antara lain,

Tipe dan kuatnya keterkuitan an- tar pemukiman dan derajal kemudaban-kemudaban yang tersedia untuk pernukim dan derajat interaksi keduanya amat menentukan pengembangan wilayab.

Pembahasan di atas menyarankan bahwa geografi membuka peluang pada geografiwan untuk mengembangkan teori yang amat dibutuhkan dalam pengembangan ilmu pengetahuan dan pembangunan

\section{DAFTAR BACAAN}

BABBIE, Earl, 1989). The practice of Social Research, (cedisi ke lima, California, Wadsworth Publishing Company

BINTARTO, R dan HADISUMARNO, Surástopo, 1979, Metode Analisa Geografi, Jakarta, L.P3ES

BROWETT, J, Revolutionary and Evolutionary Change in Modern Geographic Thought, Adelaide, Flinders University of South Australia

- BUNGE. M, 1962, "Theoretical Geography", Land Studies in Geography, Series C1, Lund, Gleerup

CHORI.EY, R.J dan IIAGGEIT. P, 1967, Models in Geography, London : The Madingley Lecturer for 1965, London.

CRAIB, Ian, 1984, Teori-Teori Sosial Modern, Jakarta, CV Radjawali

Gl:LRTZ, Clifford, 1963, Agricultural Involution: The Process of Ecologial Change in Indonesia, Barceley, University of California Press

IIAGGITI', Petter, 1966, Locational Analysis in Human Geography, New York, St. Martins Press

HARVI:Y, David 1973, Explanation in Geography, London, Edward Arnold

HARTSHORNE, R, 1959, Perspective on the nature of Geography, Oxford, Clarendon Press

JENSEN, Arild H, 1980, Geography: Its History and Concepts, london, Harper and Row Publisher

J()INSTON, R.J, 1980, "On The Nature of Fixplanation in Human Geography, Transactions of The Institute of British Geographers, 5 (4), 402.412

MCGI:1, Terry, 1971. The Urbanization Process in the Third World: Exploration in search of a theory, I.ondon, G. Bell and Sons I.TI)

ROSTOW. W.W. 1960, The Stages of Economic Growth, Berceley; Cambridge University Press 
RONDINELLI, Dennis A, 1985, Applied Methods of Regional Analysis: The Spatial Dimensions of Development Policy, London, Westview Press

SMITH, Nicl, 1979, "Geography, Science and Post-Positivist Modes of Explanation", Progress in Human Geography, 70 (2), 207-225

STODDART, I.R. 1981, Geography, Ideology and Social Concern, Oxford, Basil Blackwell

SURIASUMANTRI, Jujun. S, 1990, Hakekat Dasar Keilmuan, Jakarta, Direktorat Perguruan Tinggi Swasta, Direktorat Jenderal Pendidikan Tinggi

ZELINSKY, wILBUR, 1971, "The Hypothesis of 'The Mobility Transition", Geographycal Review, diperbanyak olch lakultas Geografi. 


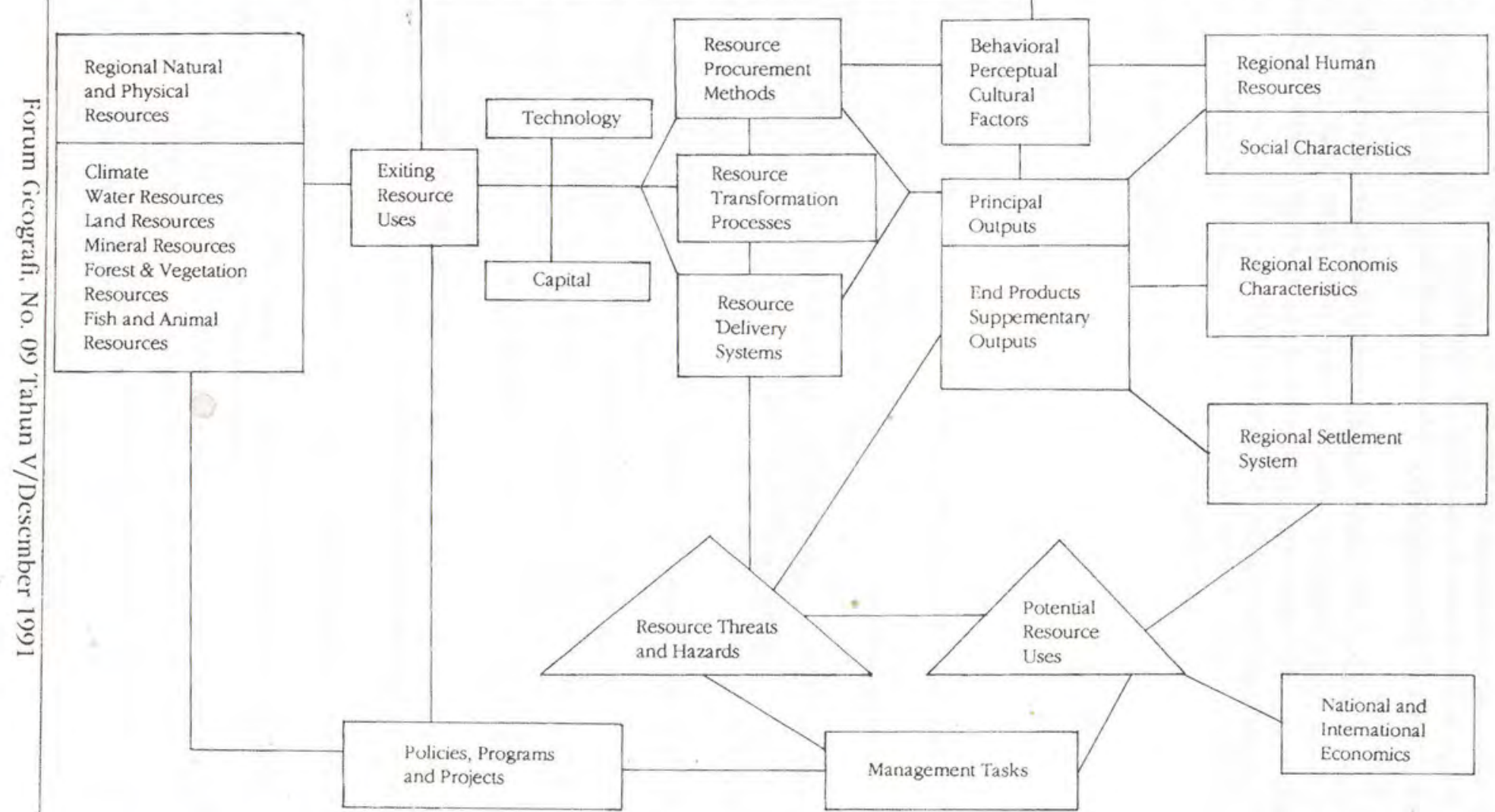

